\title{
Study on preferential selectivity of nuclear grade resin Indion-223 towards some bivalent ions
}

\author{
Pravin U. Singare ${ }^{1, *}$, Akmal L. Khan Mohammed ${ }^{1}$, N. N. Dixit ${ }^{2}$ \\ ${ }^{1}$ Department of Chemistry, Bhavan's College, Munshi Nagar, Andheri (West), \\ Mumbai - 400058, India \\ ${ }^{2}$ Department of Chemistry, Maharashtra College, Jahangir Boman Behram Marg, Nagpada, \\ Mumbai - 400008, India \\ *E-mail address: pravinsingare@gmail.com
}

\begin{abstract}
In the present paper attempts are made to understand the selectivity of nuclear grade cation exchange resin Indion-223 in $\mathrm{H}^{+}$form towards $\mathrm{Ca}^{2+}$ and $\mathrm{Mg}^{2+}$ bivalent ions in the solution based on thermodynamic concept. It was observed that with rise in temperature the equilibrium constant $K$ values for $\mathrm{H}^{+} / \mathrm{Ca}^{2+}$ uni-bivalet ion exchange reactions increases from 0.000397 to 0.000639 . Similarly for $\mathrm{H}^{+} / \mathrm{Mg}^{2+}$ uni-bivalet ion exchange reactions the equilibrium constant $K$ values increases from 0.000177 to 0.000333 . The increase in equilibrium constant values with rise in temperature indicate endothermic ion exchange reactions having the enthalpy change values of 38.92 and $51.46 \mathrm{~kJ} / \mathrm{mol}$ respectively. The difference in $\mathrm{K}$ values and enthalpy values were used to predict the selectivity behaviour of the resin towards the $\mathrm{Ca}^{2+}$ and $\mathrm{Mg}^{2+}$ bivalent ions in the solution. The thermodynamic concept of the present study can be applied to understand the selectivity behaviour of different nuclear as well as non-nuclear grade resins towards wide range of ionic species present in the exchanging liquid medium.
\end{abstract}

Keywords: bivalent exchange reactions; nuclear grade resins; cation exchange; reaction thermodynamics; enthalpy change; ionic selectivity; equilibrium constant; Indion-223

\section{INTRODUCTION}

Since their development, synthetic organic ion exchange resins are mainly used for water treatment, for instance in the preparation of demineralized water. Ion exchange resins are also having many industrial applications like purification and separations. As far as nuclear industry is concerned, one specific application is the purification of coolant and / or moderator in nuclear reactors. Particularly for CANDU- type reactors, heavy water is used as a moderator, and it is kept in high purity conditions by ion exchange resins in a purification loop. The resins remove both radiological and non-radiological impurities [1]. In nuclear power plants these resins are widely applied in- primary coolant (water) purification, treatment of primary effluents and fuel storage pond water, steam generator blow-down demineralization, for treatments of liquid waste and drainage water, purification of boric acid for recycling, condensate polishing (for nuclear power plants with boiling water reactors) [2- 
6]. Inorganic ion exchangers often have the advantage of a much greater selectivity than organic resins for certain radiologically important species, such as caesium and strontium. These inorganic materials may also prove to have advantages with respect to immobilization and final disposal when compared with organic ion exchangers. However, in nuclear power plant operations the currently available inorganic exchangers cannot entirely replace conventional organic ion exchange resins, especially in high purity water applications or in operations in which the system chemistry must be controlled through the maintenance of dissolved species such as lithium ions or boric acid [7].

These organic ion exchange resins are very effective at transferring the radioactive content of a large volume of liquid into a small volume of solid and have proved to be reliable and effective for the control of both the chemistry and radiochemistry of water coolant systems at nuclear power plants and also for processing some liquid radioactive waste [7]. As a result organic ion exchange resins are developed extensively [8-11] and various aspects of ion exchange technologies have been continuously studied to improve the efficiency and economy in various technological applications [5,6,12,13]. Development and synthesis of new organic ion exchange resins is usually followed by their characterization [14-37]. Generally the selected ion exchange materials must be compatible with the chemical nature of the liquid waste such as $\mathrm{pH}$, type of ionic species present as well as the operating parameters, in particular temperature [38-76].

Considerable work was done by previous researchers to study the properties of the ion exchange resins, to generate thermodynamic data related to various uni-univalent and heterovalent ion exchange systems [77-83]. Recently theories explaining ion exchange equilibrium between the resin phase and solution was also developed [84]. A number of researchers carried out equilibrium studies, extending over a wide range of composition of solution and resin phase [38-41,85-111]. Attempts were also made to study the temperature effect on anion exchange systems [38-41,100-111] for computing the thermodynamic equilibrium constants. However very little work was carried out to study the equilibrium of cation exchange systems [85-99]. Therefore, in the present investigation, thermodynamics study of uni-bivalent ion exchange reactions was made to predict the selectivity behaviour of strongly acidic gel type nuclear grade cation exchange resin Indion-223 towards some divalent ions in the solution.

\section{MATERIALS AND METHODS}

Glasswares: All apparatus used in the study were made up of Pyrex or Coming glass. Microburette of $0.02 \mathrm{~mL}$ accuracy was used for the entire experimental work.

Analytical balance: For weighing the sample above $25 \mathrm{mg}$, analytical balance of $0.1 \mathrm{mg}$ sensitivity was used. Metler balance was used for weighing the samples less than $25 \mathrm{mg}$.

Potentiometer: Digital potentiometer of Equiptronics make having saturated calomel electrode as a reference electrode and platinum electrode in contact with quinhydrone as an indicator electrode was used in the experimental work.

All Chemicals used were of analytical reagent (AR) grade. Distilled deionised water was used throughout the experiments for solution preparation.

Ion exchange Resin: The ion exchange resin Indion 223 as supplied by the manufacturer (Ion Exchange India Limited, Mumbai) was a strongly acidic gel type nuclear grade anion exchange resin in $\mathrm{H}^{+}$form having styrene divinyl benzene cross-linking. The resin was having 
$-\mathrm{SO}_{3}{ }^{-}$functional group, having moisture content of 50-55 \%. The operational $\mathrm{pH}$ range was 0 14 and maximum operating temperature was $120^{\circ} \mathrm{C}$.

The soluble non-polymerized organic impurities of the resin were removed by repeated Soxhlet extraction using distilled deionised water and occasionally with methanol. In order to ensure complete conversion of resins in $\mathrm{H}^{+}$form, the resins were conditioned with $0.1 \mathrm{~N} \mathrm{HCl}$ in a conditioning column. The resins were further washed with distilled deionised water until the washings were free from $\mathrm{H}^{+}$ions. The resins in $\mathrm{H}^{+}$form were air dried over $\mathrm{P}_{2} \mathrm{O}_{5}$ and used for further studies.

The ion exchange resins in $\mathrm{H}^{+}$form were equilibrated separately with $\mathrm{Ca}^{2+}$ and $\mathrm{Mg}^{2+}$ ions solution of different but known concentrations in the temperature range of $35.0-45.0^{\circ} \mathrm{C}$ for $3 \mathrm{~h}$. After $3 \mathrm{~h}$ the concentration of $\mathrm{H}^{+}$ions exchanged in the solution was determined experimentally by potentiometric titration against standard $0.1 \mathrm{~N} \mathrm{NaOH}$ solution. From the knowledge of amount of $\mathrm{H}^{+}$ions exchanged in the solution and $\mathrm{Ca}^{2+}$ and $\mathrm{Mg}^{2+}$ ions exchanged on the resin; equilibrium constant $(K)$ for the reactions

$$
\begin{aligned}
& 2 \mathrm{R}-\mathrm{H}+\mathrm{Ca}^{2+}{ }_{\text {(aq.) }} \rightleftharpoons \mathrm{R}_{2} \mathrm{Ca}+2 \mathrm{H}^{+}{ }_{\text {(aq.) }} \\
& 2 \mathrm{R}-\mathrm{H}+\mathrm{Mg}^{2+} \text { (aq.) } \rightleftharpoons \mathrm{R}_{2} \mathrm{Mg}+2 \mathrm{H}^{+}{ }_{\text {(aq.) }}
\end{aligned}
$$

were calculated. From the $K$ values obtained at different temperatures, the enthalpy change values of the above uni-bivalent ion exchange reactions were calculated.

\section{RESULTS AND DISCUSSION}

The equilibrium constants for the ion exchange reactions 1 and 2 were calculated by the equation

$$
K_{\text {app. }}=\frac{\left(\mathrm{CR}_{2} \mathrm{Y} \cdot \gamma \mathrm{R}_{2} \mathrm{Y}\right)\left(\mathrm{C}_{\mathrm{H}^{+}} \cdot \gamma_{\mathrm{H}}+\right)^{2}}{(\mathrm{CRH} \gamma \mathrm{RH})^{2}\left(\mathrm{CY}^{2+} \gamma \mathrm{Y}^{2+}\right)}
$$

here, $\mathrm{R}$ represent the resin phase and $\mathrm{Y}=\mathrm{Mg}^{2+}$ or $\mathrm{Ca}^{2+}$ bivalent ions.

The apparent equilibrium constants $\left(K_{\text {app. }}\right)$ calculated by the equation (3) were plotted versus the equilibrium concentrations of the bivalent ions in the solution (Figure 1 and 2). Lower the equilibrium concentration of the bivalent ion, lower would be its concentration in the resin and in the limiting case of zero equilibrium concentration of the bivalent ion in the solution, the resin would be in its standard state. Therefore on extrapolating the above curve to zero equilibrium concentration of bivalent ion in the solution, the equilibrium constant in the standard state, $K_{s t d}$. was obtained. Having thus obtained the equilibrium constant in the standard state, the activity coefficient ratio of ions $\gamma_{\mathrm{R}_{2} \mathrm{Y}} /\left(\gamma_{\mathrm{RH}}\right)^{2}$ at any finite equilibrium concentration of bivalent ion in the solution was calculated as the ratio of $K_{\text {std. }} / K_{\text {app }}$ (Tables 1 and 2). From the slope of the graph of $\log K_{\text {std. }}$ against 1/T (in Kelvin), the enthalpy change of the ion exchange reactions 1 and 2 were calculated (Figure 3 ). The equilibrium constant $K_{\text {std. }}$ values for the reactions 1 and 2 were found to increase with rise in temperature indicating 
endothermic ion exchange reactions having the enthalpy change values of 38.92 and $51.46 \mathrm{~kJ} /$ mol respectively (Table 3). The low enthalpy and high equilibrium values for $\mathrm{H}^{+} / \mathrm{Ca}^{2+}$ as compared to that obtained for $\mathrm{H}^{+} / \mathrm{Mg}^{2+}$ exchange indicates preferential selectivity of the Indion-223 resins in $\mathrm{H}^{+}$form towards $\mathrm{Ca}^{2+}$ ions than that towards $\mathrm{Mg}^{2+}$ ions when both of them are present in the same solution

Table 1. Equilibrium constant for the ion exchange reaction $2 \mathrm{R}-\mathrm{H}+\mathrm{Ca}^{2+}{ }_{\text {(aq.) }} \rightleftharpoons \mathrm{R}_{2} \mathrm{Ca}+2 \mathrm{H}^{+}{ }_{\text {(aq.) }}$ using Indion-223 resin

Amount of the ion exchange resin in $\mathrm{H}^{+}$form $=0.500 \mathrm{~g}$, Ion exchange capacity $=3.02$ meq. $/ 0.5 \mathrm{~g}$, Temperature $=45.0^{\circ} \mathrm{C}$.

\begin{tabular}{|c|c|c|c|c|c|c|c|c|}
\hline \multirow{2}{*}{$\begin{array}{c}\text { Initial } \\
\text { Concentration } \\
\text { of } \mathrm{Ca}^{2+} \text { ions in } \\
\text { solution } \\
\text { (M) }\end{array}$} & \multicolumn{2}{|c|}{$\begin{array}{l}\text { Equilibrium } \\
\text { concentration } \\
\text { in solution }\end{array}$} & \multicolumn{2}{|c|}{$\begin{array}{l}\text { Amount of the ions } \\
\text { in the resin } \\
\text { meq. } / 0.500 \mathrm{~g}\end{array}$} & \multirow{2}{*}{ 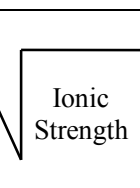 } & \multirow{2}{*}{$\frac{\left(\gamma_{\mathrm{H}}^{+}\right)^{2}}{\gamma_{\mathrm{Ca}}{ }^{2+}}$} & \multirow{2}{*}{$\begin{array}{c}\text { Apparent } \\
\text { Equilibrium } \\
\text { Constant } \\
\mathrm{K}_{\text {app. }}\end{array}$} & \multirow{2}{*}{$\frac{\left({ }^{\gamma} \mathrm{R}_{2} \mathrm{Ca}\right)}{\left({ }_{\mathrm{RH}}\right)^{2}}=\frac{\mathrm{K}_{\mathrm{std}}}{\mathrm{K}_{\mathrm{app}}}$} \\
\hline & $\begin{array}{l}\mathrm{H}^{+} \\
(\mathrm{M})\end{array}$ & $\begin{array}{l}\mathrm{Ca}^{2+} \\
(\mathrm{M})\end{array}$ & $\mathrm{H}^{+}$ & $\mathrm{Ca}^{2+}$ & & & & \\
\hline 0.0100 & 0.0069 & 0.0065 & 2.33 & 0.3464 & 0.1629 & 1.465 & 0.00068 & 0.9396 \\
\hline 0.0500 & 0.0082 & 0.0459 & 2.20 & 0.4133 & 0.3820 & 2.448 & 0.00031 & 2.0611 \\
\hline 0.1000 & 0.0085 & 0.0958 & 2.17 & 0.4250 & 0.5439 & 3.934 & 0.00027 & 2.3664 \\
\hline
\end{tabular}

Equilibrium constant in the standard state $\left(\mathrm{K}_{\text {std. }}\right)=0.000639$

Table 2. Equilibrium constant for the ion exchange reaction $2 \mathrm{R}-\mathrm{H}+\mathrm{Mg}^{2+}{ }_{\text {(aq.) }} \rightleftharpoons \mathrm{R}_{2} \mathrm{Mg}+2 \mathrm{H}^{+}{ }_{\text {(aq.) }}$ using Indion-223 resin

Amount of the ion exchange resin in $\mathrm{H}^{+}$form $=0.500 \mathrm{~g}$, Ion exchange capacity $=3.02$ meq. $/ 0.5 \mathrm{~g}$, Temperature $=45.0^{\circ} \mathrm{C}$.

\begin{tabular}{|c|c|c|c|c|c|c|c|c|}
\hline \multirow{2}{*}{$\begin{array}{c}\text { Initial } \\
\text { Concentration } \\
\text { of } \mathrm{Mg}^{2+} \text { ions in } \\
\text { solution } \\
\text { (M) }\end{array}$} & \multicolumn{2}{|c|}{$\begin{array}{l}\text { Equilibrium concentration } \\
\text { in solution }\end{array}$} & \multicolumn{2}{|c|}{$\begin{array}{l}\text { Amount of the ions } \\
\text { in the resin } \\
\text { meq. } / 0.500 \mathrm{~g}\end{array}$} & \multirow{2}{*}{ 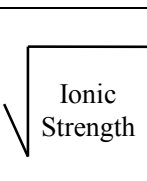 } & \multirow{2}{*}{$\frac{\left(\gamma_{\mathrm{H}}^{+}\right)^{2}}{\gamma_{\mathrm{Mg}}{ }^{2+}}$} & \multirow{2}{*}{$\begin{array}{c}\text { Apparent } \\
\text { Equilibrium } \\
\text { Constant } \\
\mathrm{K}_{\text {app. }}\end{array}$} & \multirow{2}{*}{$\frac{\left({ }_{\mathrm{R}_{2} \mathrm{Mg}}\right)}{\left({ }_{\mathrm{RH}}^{\gamma}\right)^{2}}=\frac{\mathrm{K}_{\mathrm{std}}}{\mathrm{K}_{\text {app. }}}}$. \\
\hline & $\begin{array}{l}\mathrm{H}^{+} \\
(\mathrm{M})\end{array}$ & $\begin{array}{l}\mathrm{Mg}^{2+} \\
(\mathrm{M})\end{array}$ & $\mathrm{H}^{+}$ & $\mathrm{Mg}^{2+}$ & & & & \\
\hline 0.0100 & 0.0058 & 0.0071 & 2.44 & 0 & 0.165 & 1.47 & 0.00034 & 0.979 \\
\hline 0.0500 & 0.0074 & 0.0463 & 2.28 & 0.370 & 0.382 & 2.45 & 0.00021 & 1.585 \\
\hline 0.1000 & 0.0077 & 0.0961 & 2.25 & 0.387 & 0.544 & 3.58 & 0.00017 & 1.957 \\
\hline
\end{tabular}

Equilibrium constant in the standard state $\left(\mathrm{K}_{\text {std. }}\right)=0.000333$

Table 3. Thermodynamics of ion exchange reactions using Indion-223 resin Amount of the ion exchange resin in $\mathrm{H}^{+}$form $=0.500 \mathrm{~g}$, Ion exchange capacity $=3.02 \mathrm{meq} . / 0.5 \mathrm{~g}$

\begin{tabular}{|c|c|c|c|c|c|c|}
\hline Reactions & \multicolumn{3}{|c|}{1} & \multicolumn{3}{c|}{2} \\
\hline $\begin{array}{c}\text { Temperature }\left({ }^{\circ} \mathrm{C}\right) \\
\begin{array}{c}\text { Equilibrium Constant } \\
\left(\mathrm{K}_{\text {std. }}\right)\end{array}\end{array}$ & 35.0 & 40.0 & 45.0 & 35.0 & 40.0 & 45.0 \\
\hline $\begin{array}{c}\text { Enthalpy Change } \Delta \mathrm{H}^{\mathrm{o}} \\
\left(\mathrm{kJ} . \mathrm{mol}^{-1}\right)\end{array}$ & 0.000397 & 0.000629 & 0.000639 & 0.000177 & 0.000256 & 0.000333 \\
\hline
\end{tabular}




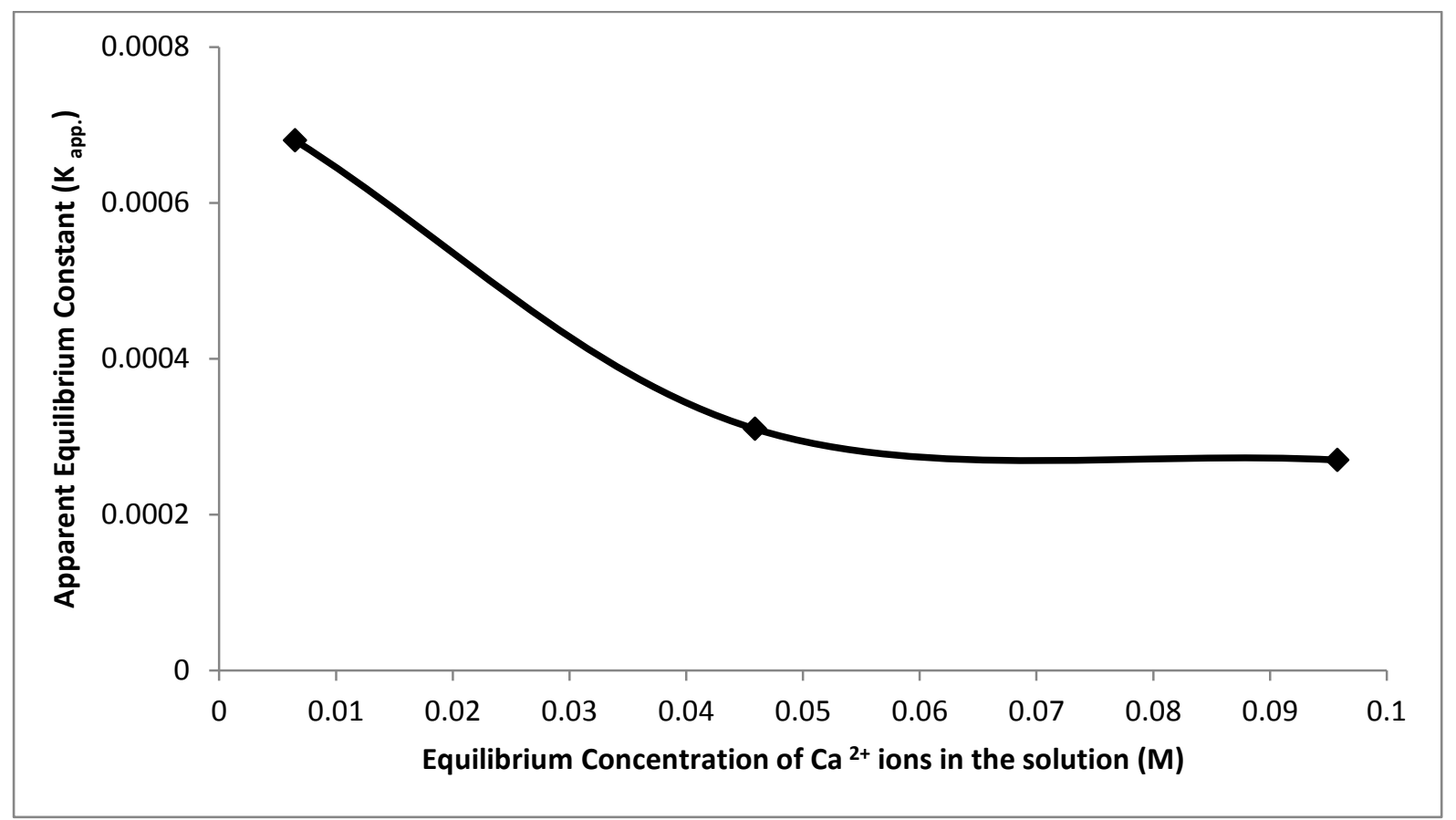

Figure 1. Variation of apparent equilibrium constant with equilibrium concentration of $\mathrm{Ca}^{2+}$ ions in solution for the ion exchange reaction (1) using ion exchange resin Indion-223. Amount of the ion exchange resin in $\mathrm{H}^{+}$form $=0.500 \mathrm{~g}$, Ion exchange capacity $=3.02$ meq. $/ 0.5 \mathrm{~g}$, Temperature $=45.0^{\circ} \mathrm{C}$.

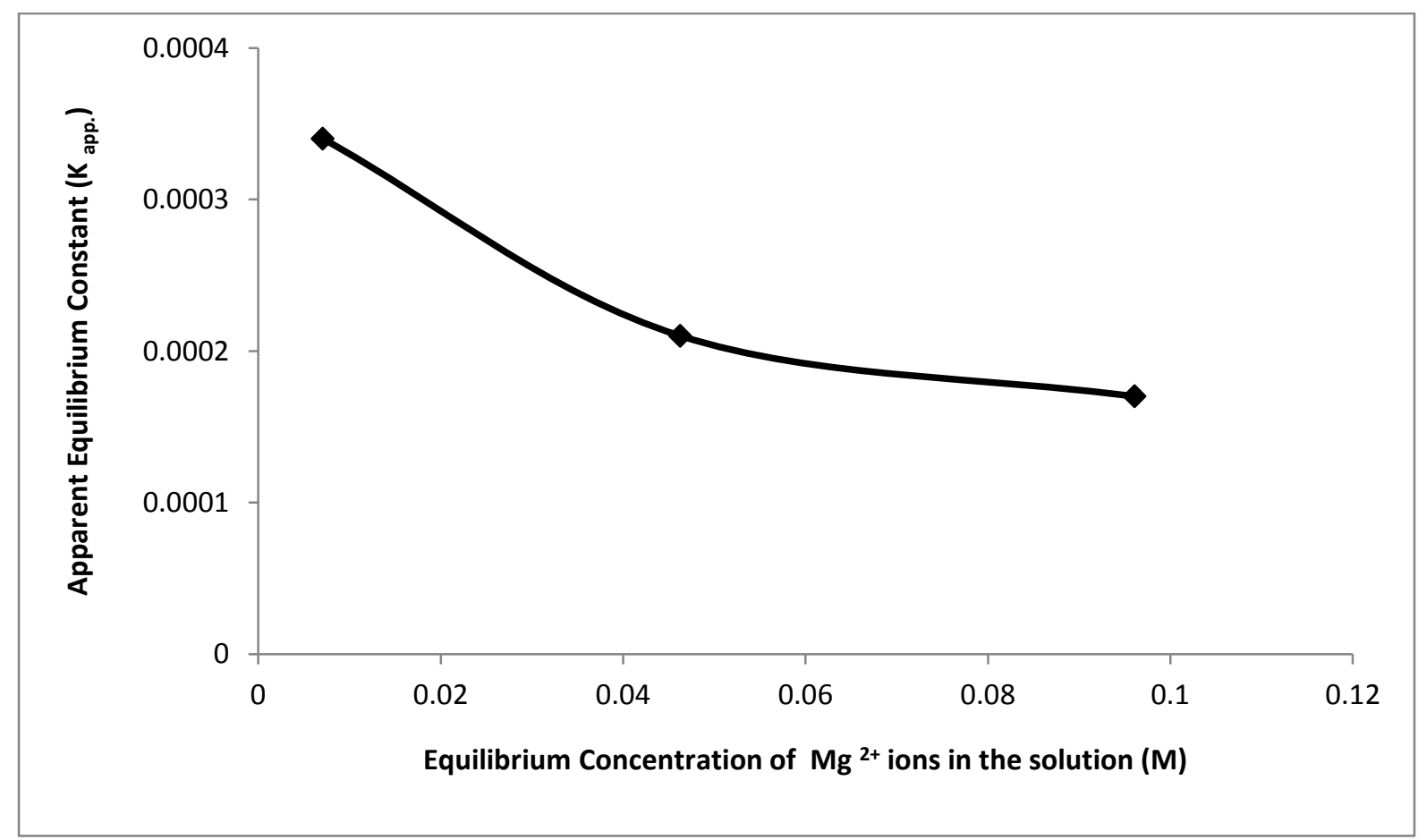

Figure 2. Variation of apparent equilibrium constant with equilibrium concentration of $\mathrm{Mg}^{2+}$ ions in solution for the ion exchange reaction (2) using ion exchange resin Indion-223. Amount of the ion exchange resin in $\mathrm{H}^{+}$form $=0.500 \mathrm{~g}$, Ion exchange capacity $=3.02$ meq. $/ 0.5 \mathrm{~g}$, Temperature $=45.0^{\circ} \mathrm{C}$. 


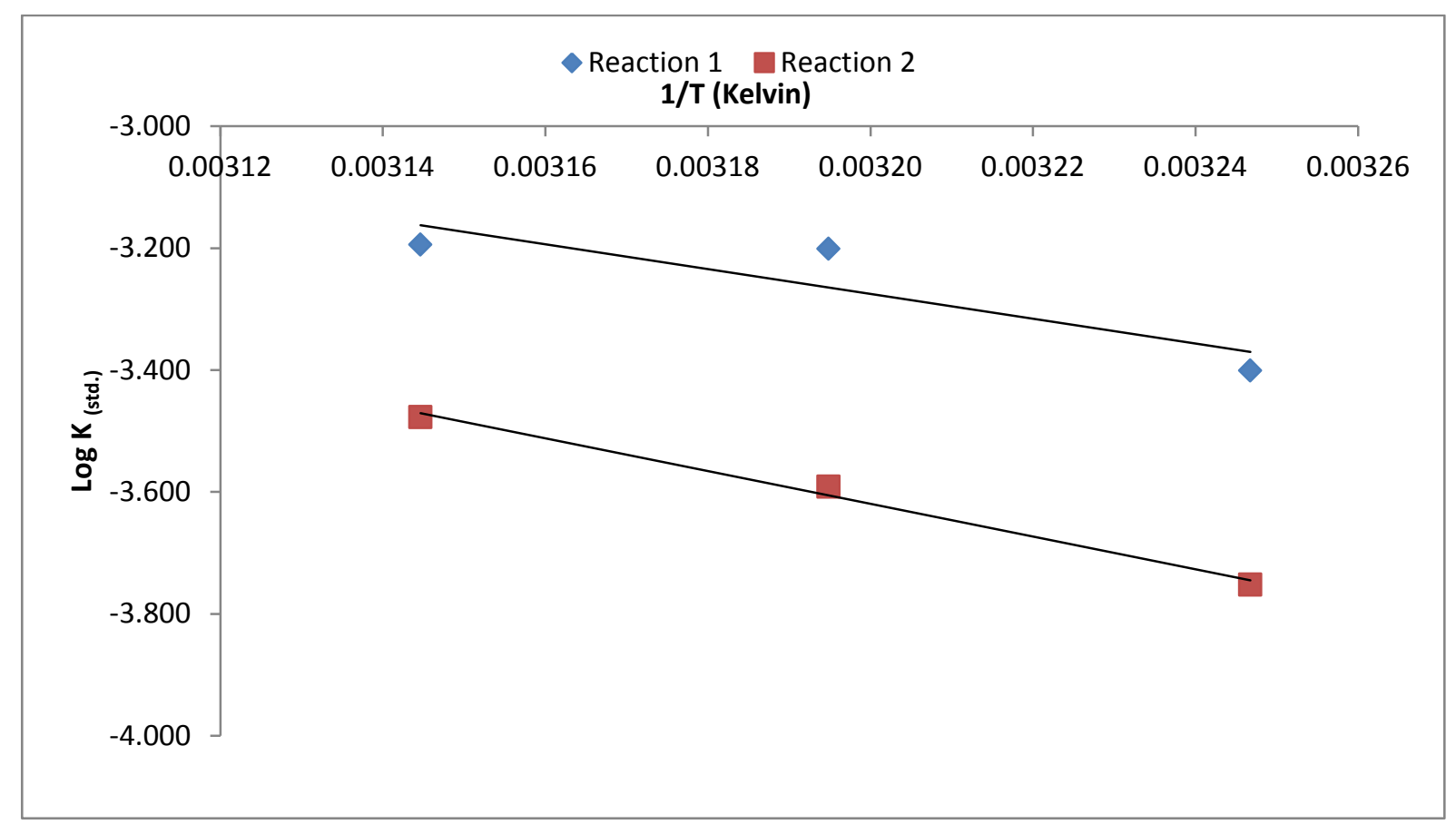

Figure 3. Variation of equilibrium constant with temperature for uni-bivalent ion exchange reactions performed by using Indion-223 resins.

\section{CONCLUSION}

From the results of present study, it appears that the experimental technique used here can be applied further to understand the ionic selectivity of different industrial grade ion exchange resins. It is expected that such studies will provide valuable information in order to decide about the selection of those resins for efficient separation of various ionic species present in the industrial waste water effluents.

\section{References}

1. C. Simister, F. Caron, R. Gedye, Journal of Radioanalytical and Nuclear Chemistry, 261(3), 523-531(2004).

2. J.R. Kaczvinsky, J.S. Fritz, D.D. Walker, M.A. Ebra, Journal of Radioanalytical and Nuclear Chemistry, 91(2), 349-360 (1985).

3. A.H. Bond, M.J. Gula, J.T. Harvey, J.M. Duffey, E.P. Horwitz, S.T. Griffin, R.D.Rogers, J.L. Collins, Ind.Eng. Chem. Res., 38 (4), 1683-1689 (1999).

4. A.H. Bond, F.W.K. Chang, A.H. Thakkar, J.M. Williamson, M.J. Gula, J.T. Harvey, S.T. Griffin, R.D. Rogers, E.P. Horwitz, Ind. Eng. Chem. Res., 38 (4), 1676-1682 (1999).

5. S.K. Samanta, M. Ramaswamy, B.M. Misra, Sep. Sci. Technol., 27, 255-267(1992).

6. S.K. Samanta, T.K. Theyyunni, B.M. Misra, J. Nucl. Sci. Technol., 32, 425-429 (1995). 
7. Application of Ion Exchange Processes for the Treatment of Radioactive Waste and Management of Spent Ion Exchangers, International Atomic Energy Agency, Technical Reports Series No. 408, IAEA, Vienna (2002).

8. M. Tomoi, K. Yamaguchi, R. Ando, Y. Kantake, Y. Aosaki, H. Kubota, J. Appl. Poly. Sci., 64(6), 1161-1167 (1997).

9. L. Zhu, Y. Liu, J. Chen, Ind. Eng. Chem. Res., 48 (7), 3261-3267 (2009).

10. K.F. Hassan, S.A. Kandil, H.M. Abdel-Aziz, T. Siyam, Chromatography Research International, 2011, Article ID 638090, 6 pages (2011).

11. S.A. Patel, B.S. Shah, R.M. Patel, P.M. Patel, Iranian Polymer Journal, 13(6), 445-453 (2004).

12. R. Kumaresan, K.N. Sabharwal, T.G. Srinivasan, P.R. Vasudeva Rao, G. Dhekane, Solvent Extraction and Ion Exchange, 24(4), 589-602 (2006).

13. L.S. Deborah, K. Nazila, B.K. Douglas, A.D. James, Geochemical Transactions, 14:1 (2013).

14. P.U. Singare, Journal of Analytical Science and Technology, 5:30 (2014).

15. P.U. Singare, Kerntechnik, 79 (1), 51-57(2014).

16. P.U. Singare, Diffusion Fundamentals Online Journal, 19(4), 1-21 (2013).

17. P.U. Singare, Journal of Radioanalytical and Nuclear Chemistry, 299:591-598 (2014).

18. P.U. Singare, International Journal of Nuclear Energy Science and Technology, 8(2), 157-170 (2014).

19. P.U. Singare, Nuclear Engineering and Technology, 46(1), 93-100 (2014).

20. P.U. Singare, Colloid Journal, 76(2), 193-201(2014).

21. P.U. Singare, Journal of Nuclear Energy Science \& Power Generation Technology, 2(2), 1-6 (2013).

22. P.U. Singare, International Letters of Chemistry, Physics and Astronomy 13 (2013) 37-49.

23. P.U. Singare, International Letters of Chemistry, Physics and Astronomy 13 (2013) 50-62.

24. P.U. Singare, International Letters of Chemistry, Physics and Astronomy 13 (2013) 63-76.

25. P.U. Singare, International Letters of Chemistry, Physics and Astronomy 13 (2013) 77-89.

26. P.U. Singare, International Letters of Chemistry, Physics and Astronomy 12 (2013) 1-13.

27. P.U. Singare, International Letters of Chemistry, Physics and Astronomy 12 (2013) 14-27.

28. P.U. Singare, International Letters of Chemistry, Physics and Astronomy 6 (2013) 1-5.

29. P.U. Singare, R.S. Lokhande, Ionics, 18(4), 351-357 (2012).

30. P.U. Singare, Journal of Modern Chemistry \& Chemical Technology, 5(1), 34-44 (2014).

31. P.U. Singare, Journal of Nuclear Engineering \& Technology, 4(1), 13-24 (2014).

32. P.U. Singare, Journal of Nuclear Engineering \& Technology,4(1), 1-12 (2014).

33. P.U. Singare, Journal of Nuclear Engineering \& Technology, 3(3), 1-11 (2013). 
34. P.U. Singare, Journal of Nuclear Engineering \&Technology, 3(2), 14-24 (2013).

35. R. N. Singru, Archives of Applied Science Research, 3 (5):309-325 (2011).

36. R. N. Singru, ISRN Thermodynamics, 2012 (2012), Article ID 323916, 8 pages doi:10.5402/2012/323916.

37. Y. H. Ju, O. F. Webb, S. Dai, J. S. Lin, C. E. Barnes, Ind. Eng. Chem. Res., 39 (2), 550-553 (2000).

38. P.U. Singare, A.N. Patange, International Letters of Chemistry, Physics and Astronomy 11(1) (2014) 67-73.

39. P.U. Singare, A.N. Patange, International Letters of Chemistry, Physics and Astronomy 11(1) (2014) 44-50.

40. P. U. Singare, A. N. Patange, International Letters of Chemistry, Physics and Astronomy $6(2014) 8-15$.

41. P. U. Singare, A. N. Patange, International Letters of Chemistry, Physics and Astronomy $6(2014) 1-7$.

42. P.U. Singare, R.S. Lokhande, R.S. Madyal, Open Journal of Physical Chemistry 1(2), 45-54 (2011).

43. P.U.Singare, R.S.Lokhande, R.S. Madyal, Rus. J. Gen. Chem., 80(3), 527-532 (2010).

44. R.S.Lokhande, P.U.Singare, S.R.D. Tiwari, Russ.J. Gen.Chem., 80 (10), 2054-2058 (2010).

45. P.U.Singare, R.S.Lokhande, N.G.Samant, M.R.Dhatrak, Colloid Journal, 72(4), 538543(2010).

46. P.U.Singare, R.S.Lokhande, N.Samant, Natural Science, 1(2), 124-128 (2009).

47. R.S. Lokhande, P.U.Singare, M.H.Dole, Russ. J. Physical Chemistry, 83(13), 2313-2317 (2009).

48. P.U. Singare, R.S. Lokhande, T.S. Prabhavalkar, Bull. Chem. Soc. Ethiop., 22(3), 415421 (2008).

49. R.S. Lokhande, P.U. Singare, A.R. Kolte, Bull. Chem. Soc. Ethiop., 22(1), 107-114 (2008).

50. R. S. Lokhande, P. U. Singare, A. B. Patil, Russian Journal of Physical Chemistry A, 81(12), 2059-2063 (2007).

51. P.U.Singare, R.S.Lokhande, M.B. Nadar, Oriental Journal of Chemistry, 25(4), 879-883 (2009).

52. P.U.Singare, R.S.Lokhande, M.B. Nadar, Oriental Journal of Chemistry, 25(3), 755-758 (2009).

53. P.U.Singare, R.S.Lokhande, M.B. Nadar, Oriental Journal of Chemistry, 25(3), 587-592 (2009).

54. P.U.Singare, R.S.Lokhande, M.R.Dhatrak (M.D.Karad), Oriental Journal of Chemistry, 25(3), 687-693 (2009). 
55. P.U.Singare, R.S.Lokhande, Rochelle D'Souza, Rasāyan Journal of Chemistry, 2(2), 507-511, (2009).

56. P.U.Singare, R.S.Lokhande, Rochelle D'Souza, Rasāyan Journal of Chemistry, 2(4), 941-945 (2009).

57. P.U.Singare, R.S.Lokhande, Rochelle D'Souza, Rasāyan Journal of Chemistry, 2(3), 645-648 (2009).

58. P.U.Singare, R.S.Lokhande, S.Y.Pimple, Rasāyan Journal of Chemistry, 2(1), 75-80 (2009).

59. P.U.Singare, R.S.Lokhande, S.Y.Pimple, Rasāyan Journal of Chemistry, 2(2), 315-321 (2009).

60. P.U.Singare, R.S.Lokhande, S.Y.Pimple, Rasāyan Journal of Chemistry, 2(3), 617-621 (2009).

61. P.U.Singare, R.S.Lokhande, P.C.Vartak, Rasāyan Journal of Chemistry, 2(1), 96-100 (2009).

62. P.U.Singare, R.S.Lokhande, P.C.Vartak, Rasāyan Journal of Chemistry, 2(2), 491-496 (2009).

63. P.U.Singare, R.S.Lokhande, P.C.Vartak, Rasāyan Journal of Chemistry, 2(4), 807-812 (2009).

64. P.U.Singare, R.S.Lokhande, M.G.Patil, Rasāyan Journal of Chemistry, 2 (1), 114-119 (2009).

65. P.U.Singare, R.S.Lokhande, M.G.Patil, Rasāyan Journal of Chemistry, 2(3), 566-571 (2009).

66. P.U.Singare, R.S.Lokhande, M.G.Patil, Rasāyan Journal of Chemistry, 2(4), 861-864 (2009).

67. P.U.Singare, R.S.Lokhande, N.P.Vanmali, Rasāyan Journal of Chemistry, 2(2), 280-284 (2009).

68. P.U.Singare, R.S.Lokhande, N.P.Vanmali, Rasāyan Journal of Chemistry, 2(2), 280-284 (2009).

69. P.U.Singare, R.S.Lokhande, N.P.Vanmali, Rasāyan Journal of Chemistry, 2(3), 593-597 (2009).

70. P.U.Singare, R.S.Lokhande, N.P.Vanmali, Rasāyan Journal of Chemistry, 2(4), 901-906 (2009).

71. P.U.Singare, R.S.Lokhande, V.Y.Pattebahadur, Int. J. Chem. Sci., 7(2), 797-804 (2009).

72. P.U.Singare, R.S.Lokhande, V.Y.Pattebahadur, Int. J.Chem. Sci., 7(2), 722-730 (2009).

73. P.U.Singare, R.S.Lokhande, V.Y.Pattebahadur, Int. J. Chem. Sci., 7(2), 1472-1478 (2009).

74. P.U.Singare, R.S.Lokhande, A.R.Kolte, M.H.Dole, P.Karthikeyan, S.A.Parab, Int. J. Chem. Sci., 6(4), 2172-2181 (2008).

75. R.S.Lokhande, P.U.Singare, P.Karthikeyan, Journal of Indian Council of Chemists, 25(2), 117-121 (2008). 
76. R.S.Lokhande, P.U.Singare, Journal of Indian Council Chemists, 24(02), 73-77 (2007).

77. N.N. Andreev, Yu.I.Kuznetsov, Russian Journal of Physical Chemistry, 64, 1537 (1990).

78. A. Bhargava, C. Janardanan, Indian Journal of Chemistry, 36A, 624 (1997).

79. D. Muraviev, A. Gonzalo, M. Valiente, Anal. Chem., 67, 3028 (1995).

80. G.E. Boyd, F. Vaslow, S. Lindenbaum, J. Phys. Chem., 71, 2214 (1967).

81. J.F. Duncan, Aus.J.Chem.Soc., 8, 1 (1955).

82. G.E. Boyd, F. Vaslow, S. Lindenbaum, J.Phys.Chem., 68, 590 (1964).

83. A. Schwarz, G.E. Boyd, J. Phys. Chem., 69, 4268 (1965).

84. N.I. Gamayunov, Russ. J. Phys. Chem., 64, 1787 (1990).

85. G.E. Boyd, G.E. Myers, J. Phys. Chem., 60, 521 (1956).

86. O.D. Bonner, J. Phys. Chem., 59, 719 (1955).

87. O.D.Bonner, J. Phys. Chem., 58, 318 (1954).

88. S.Lindenbaum, C.F.Jumper, G.E. Boyd, J. Phys. Chem., 63, 1924 (1959).

89. K.A. Kraus, R.J. Raridon, J.Phys.Chem., 63, 1901 (1959).

90. O.D.Bonner, W.H. Payne, J.Phys.Chem., 58,183 (1954).

91. W.J.Argersinger, A.W. Davidson, J.Phys.Chem., 56, 92 (1952).

92. O.D.Bonner, R.R. Pruett, J.Phys.Chem., 63, 1420 (1959).

93. O.D.Bonner, F.L.Livingston, J.Phys.Chem., 60, 530 (1956).

94. O.D.Bonner, L.L.Smith, J.Phys.Chem., 61, 326 (1957).

95. O.D.Bonner, C.F.Jumper, O.C.Rogers, J. Phys. Chem., 62, 250 (1958).

96. O.D.Bonner, L.L.Smith, J.Phys.Chem., 61, 1614 (1957).

97. J.Kielland, J. Soc. Chem. Ind., (London) 54, 232 (1935).

98. A.P.Vanselow, J. Am. Chem. Soc., 54, 1307(1932).

99. G.L. Gaines (Jr.), H.C.Thomas, J.Chem.Phys., 21, 714 (1953).

100.K.A.Kraus, R.J.Raridon, D.L. Holcomb, Chromatogr. J., 3,178 (1960).

101. R.S. Lokhande, P.U. Singare, A.B. Patil, Russ. J. Phys. Chem. A, 81, 2059 (2007).

102. P.U. Singare, R.S. Lokhande, T.S. Prabhavalkar, Bull. Chem. Soc. Ethiop., 22, 415 (2008).

103. R.S. Lokhande, P. U. Singare, J. Ind. Council Chem., 24, 73 (2007).

104. R.S. Lokhande, P.U. Singare, A.R. Kolte, Bull. Chem. Soc. Ethiop., 22, 107 (2008).

105. K.G.Heumann, K. Baier, Chromatographia, 15, 701 (1982).

106. O.D. Bonner, G.Dickel, H.Brummer, Z. Physik. Chem., (Frankfurt), 25, 81 (1960).

107. G.L.Starobinet, V.S. Soldatov, A.A.Krylova, Russ. J. Phys. Chem., 41, 194 (1967). 
108. Pravin U. Singare, Akmal L. Khan Mohammed, N. N. Dixit, International Letters of Chemistry, Physics and Astronomy 14(2) (2014) 127-135.

109. Pravin U. Singare, Akmal L. Khan Mohammed, N. N. Dixit, International Letters of Chemistry, Physics and Astronomy 14(2) (2014) 190-198.

110. Pravin U. Singare, Akmal L. Khan Mohammed, N. N. Dixit, International Letters of Chemistry, Physics and Astronomy 14(2) (2014) 199-207.

111. Pravin U. Singare, Akmal L. Khan Mohammed, N. N. Dixit, International Letters of Chemistry, Physics and Astronomy 14(2) (2014) 231-239. 